\title{
Identification of the degree of impact of dams on the hydrologic regime of semi-arid rivers: an evaluation of the DHRAM method
}

\section{Identificação do grau de impacto de barragens sobre o regime hidrológico em rios do semiárido: uma avaliação do método DHRAM}

\author{
Naiah Caroline Rodrigues de Souza ${ }^{1}$, Andrea Sousa Fontes ${ }^{2}$, Lafayette Dantas da Luz ${ }^{1}$ and \\ Sandra Maria Conceição Pinheiro ${ }^{2}$ \\ ${ }^{1}$ Universidade Federal da Bahia, Salvador, BA, Brasil \\ ${ }^{2}$ Universidade Federal do Recôncavo da Bahia, Cruz das Almas, BA, Brasil \\ E-mails: naih.carol@gmail.com (NCRS), andreafontes@ufrb.edu.br (ASF), lluz@ufba.br (LDL), sandramcpinheiro@yahoo.com.br (SMCP)
}

Received: July 01, 2016 - Revised: September 30, 2016 - Accepted: November 08, 2016

\begin{abstract}
The flow regulation that results from the implantation of dams causes consequences to the river ecosystems due to the modification on the characteristics of the hydrologic regime. The investigation of these changes become relevant, mainly in semi-arid regions where there is a great amount of these hydraulic structures and lack of such analyzes. Considering the above, this paper aims to evaluate the Dundee Hydrological Regime Alteration Method (DHRAM) through the classification of the degree of impact of dams located on rivers Itapicuru, Paraguaçu and their tributaries, verifying the adequacy of its use to represent the semi-arid hydrologic regime. Thereby, the DHRAM was applied in three versions: considering the thresholds that define the scores to classify the degree of impact in its original set (accordingly to Black et al. (2005)); with the adjustment of those thresholds to local conditions; and, with the regrouping of variables and adjustment of thresholds. The results showed that the method in its original set is applicable to semi-arid rivers, however it tends to be very restrictive against the high natural hydrologic variability characteristic of these rivers, and it ends up pointing to a high degree of alteration for dams that are known for not causing a very siginifcant flow regulation. The DHRAM with the regrouping of variables and the adjustment of thresholds presented the classification that approached the most to the known characteristics of the studied dams, being useful for the evaluation of the impact of dams still in project, and also to guide the adoption of operating rules that minimize the most significant hydrologic alterations that are identified.
\end{abstract}

Keywords: Hydrologic indicators; Classification of the degree of impact; Semi-arid.

\section{RESUMO}

A regulação de vazões que ocorre a partir da implantação de barragens provoca consequências sobre ecossistemas fluviais devido às modificações nas características do regime hidrológico. A investigação dessas modificações ganha relevância, principalmente em regiões de semiárido onde há grande presença dessa obra hidráulica e carência de tais análises. Diante disso, o presente artigo teve como objetivo avaliar o Dundee Hydrological Regime Alteration Method (DHRAM) a partir da classificação do grau de impactos de barragens localizadas nos rios Itapicuru, Paraguaçu e seus afluentes, verificando a adequação de seu uso para representação de regime hidrológico de semiárido. Aplicou-se, então, o DHRAM em três versões: considerando os limiares que definem a pontuação para a classificação do grau de impacto na sua forma original (conforme Black et al. (2005)); com ajuste desses limiares às condições locais; e com reagrupamento das variáveis e ajuste nos limiares. Os resultados mostraram que o método em sua forma original é aplicável para rios de semiárido, entretanto tende a ser muito restritivo frente a alta variabilidade hidrológica natural característica desses rios, e acaba por apontar um grau de alteração elevado para barragens reconhecidas como não regularizadoras. O DHRAM com reorganização das variáveis e ajuste de limiares apresentou a classificação que mais se aproximou das características conhecidas das barragens estudadas, mostrando-se útil para avaliação do impacto por barragens ainda em projeto, e também, para orientar a adoção de regras de operação que minimizem as alterações hidrológicas mais significativas que sejam identificadas.

Palavras-chave: Indicadores hidrológicos; Classificação do grau de impacto; Semiárido. 


\section{INTRODUCTION}

Ecosystems evolve naturally from variations of conditioning factors, whether biotic or not, in time and space. Thus, aquatic ecosystems are set having also as a significant basis the flow regime and its variability. As the flow regime is the driving force in river ecosystems (JUNK et al., 1989; STANFORD et al., 1996; POFF et al., 1997; BUNN; ARTHINGTON, 2002; BATALLA et al., 2004), the alterations of parameters that characterize hydrologic variability can cause dramatic effects on aquatic organisms, riverside species, flow of energy within the system, sediment movement and interactions in the floodplain (POFF et al., 1997).

However, aiming to maximize the provision of goods and service to society, intensive anthropic actions have disturbed conditioning elements related to the referred ecosystems in different ways. Regarding aquatic ecosystems, or those dependent on this one, the implementation of reservoirs in the country has provoked several interferences, among those there are alterations on the connectivity of the river with the riparian zone and the disturbance of the hydrological regime as Stevaux et al. (2012) identified in the Paraná River, in Brazil. Moreover, for example, there are the alterations of the aspects of the flow regime referring to magnitude, frequency, duration, seasonality and alteration rates highlighted by Genz and Luz (2012) in the low course of the São Francisco River due to the implantation of large dams. The implantation of reservoirs causes alteration in the water quality as well (FANTIN-CRUZ et al., 2015), besides geomorphological alteration and on sediment transport.

Nonetheless, the systematization of metrics to characterize the effects of alterations provoked on the ecosystems due to the installation of dams is still an area needy of development. In search of this systematization, Richter et al. (1996) presented a method whose objective is to evaluate hydrological alteration through analyzing hydrological variables to identify possible impacts over the flow regime (Indicators of Hydrologic Alteration - IHA). Poff et al. (1997) proposed to analyze hydrologic variables that have relevant attributes in the river ecosystems processes and suggested that those should be incorporated in the management of rivers by the maintenance of the five aspects considered ecological relevant of the flow regime, being those: magnitude, frequency, duration, timing and rate of rise and fall. Other methods concerning the evaluation of hydrologic alterations have been being proposed, such as the National Hydrologic Assessment Tool - NATHAT (OLDEN; POFF, 2003; CADE, 2006), the Aggregate Index of Hydrological AlterationAIHA (DITTMANN et al., 2009), the Índices de Alteración Hidrológica em Rios-LAHRIS (MARTINÉZ; YUSTE, 2010). However, Brazil has its first hydrologic alteration analysis limited to a few places and for large reservoirs (GENZ, 2006; AGOSTINHO et al., 2007; SOUZA, 2009; SANTOS; SOUZA, 2015).

Among the factors that can explain the limited number of analysis there is the complexity of processes that demand monitoring and multidisciplinary teams. In such cases, purely hydrological methods become an interesting tool to develop preliminary analysis (SOUZA, 2009).

Aiming to represent the degree of the hydrologic alteration of a water body, Richter et al. (1997) presented a systematic analysis for the alterations considering a admissible range of variation, the Range of Variability Approach- RVA. Black et al. (2005), on the other hand, developed another method to evaluate the degree of alterations on the flow regime due to anthropic modifications, the Dundee Hydrological Alteration Method (DHRAM). Both use the IHA's statistical basis.

It is important to highlight that the DHRAM was developed from study cases of impacted and non-impacted watersheds from Scotland and Ireland (BLACK et al., 2005) and their application are few in regions whose rivers have different flow regimes. For instance, the application made by Zhang et al. (2015) that investigated hydrologic alterations on the flow regime of the East River watershed, in China, influenced by reservoirs, through different methodologies, among those the DHRAM. In Brazil, Genz and Lessa (2015) applied DHRAM in its original form and evaluated the degree of impact of Pedra do Cavalo Dam, located in an humid region, in the lower course of the Paraguaçu River, but that drains in regions with characteristics of semi-arid to humid.

The DHRAM is indicated to classify the hydrological alterations because it relates the ecological impact in a concept of risk, using the assumption that damaging risks to the structure of the ecosystem increase directly the cumulative distortion of the hydrological regime. According to its authors, DHRAM can be applied in any country. Although, it might be possible the need of some arrangements using local data, as it was pointed out by Lima (2014), primarily on the thresholds of the hydrologic alterations used to attribute the points of impact of the method, as they may not be suitable to the flow regime of rivers different from those from Europe, for example the rivers located in regions of tropical weather. Such need can be related to the elaboration of the said method that, besides basing and validating its thresholds from studies applied in rivers from regions of climate, hydrologic variability, topography and conditions of use different from Brazilian rivers, above all the semi-arid from Bahia, it synthetically uses the results of the Indicators of Hydrologic Alteration - IHA (RICHTER et al., 1996). This synthesized outcome transforms in a unique value the results of the variables of IHA gathered in a same group of hydrological indicators and variables. However, those variables have different meaning and this synthesis can affect the results of the classification obtained. Furthermore, to ponder the same weight/relevance for all the five groups considered in IHA and in DHRAM, that relate in a different way depending on the hydrological regime in study, can also influence on the results obtained. So, the application of this method for water courses from the semi-arid of Bahia must be done judiciously, along the investigation of representativeness of its results.

In the state of Bahia, the watersheds of Paraguaçu River and Itapicuru River are important river systems situated in a critical region in reference of the water resources management, like the semi-arid in Bahia, and it has been being a research focus area (GENZ, 2006; LIMA, 2014; SANTOS et al., 2015) that aims to characterize and evaluate the alterations on these river systems due to the implantation of dams. These dams are neighbors and they are in similar climatic regions. On the Itapicuru River Watershed, there are implanted 56 dams and, from those considered big dams, just 4 (Aipim, Pedras Altas, Pindobaçu and Ponto Novo) have physical, operational data and time series available, while in the Paraguaçu Watershed there are 59 dams, being 7 of them considered large and with data available. Studies 
such as Vaz Sampaio (2006) and Sokolonski and Costa (1996) indicated the fragility of ecosystems in these hydrological basins and the socioeconomic and environmental risks associated to the activities developed in them.

Considering what was observed, this paper objectifies to evaluate the application of the DHRAM regarding the classification of the degree of impacts caused by dams situated in the Itapicuru and Paraguaçu rivers as well as their tributaries, verifying the adequacy of its use to represent the characteristics of semi-arid rivers. This evaluation aims to contribute to procedures that base preliminary studies, projects and definition of operating rules for dams, considering, among other targets, the minimization of the effects on the river ecosystem due to the alterations on the hydrological regime.

\section{STUDY AREA}

The Itapicuru River Watershed is located in the northeast region of the state of Bahia, covering an area of $6.51 \%$, and the drained area by the basin corresponds to $36,440 \mathrm{~km}^{2}$ (ANA, 2014). The Itapicuru is distributed in sub-humid units to humid (Am) and semi-arid (BSh), according to Köpper-Geiger's classification, being the semi-arid climate present in $81 \%$ of the watershed's area. To North, near Chapada Diamantina, the climate in the watershed varies between sub-humid and dry, occurring even $900 \mathrm{~mm}$ of rainfall (INEMA, 2014b). Itapicuru River main headwater is situated to the north of Senhor do Bonfim city, where it receives the name Itapicuru-Açu. The water body keeps that name until the confluence with Itapicuru-Mirim River and, then, it becomes in fact the Itapicuru. On the watershed of these two rivers (Itapicuru-Mirim and Itapicuru-Açu) were implanted several barrages, highlighting Ponto Novo, Pedras Altas, Pindobaçu and Aipim.

The Paraguaçu River Watershed is considered as the most important river system, whose domain is entirely state-owned, located in the east center region of Bahia and has an area of $55,317 \mathrm{~km}^{2}$, which corresponds to approximately $10.14 \%$ of Bahia's territory (BAHIA, 1993). The Paraguaçu Watershed has a diversity of its climatic regions. The headwaters situated in Chapada Diamantina present mountain climate, according to Köppen-Geiger, varying from humid to sub-humid - Am, whereas in the middle zone, the dominant climate is semi-arid - BSh (SILVA, 2012), predominating in $67 \%$ of the area of the basin. This watershed has five important reservoirs: Apertado, Bandeira de Melo, Pedra do Cavalo, França and São José do Jacuípe. The first three are situated in the main river and the others in the Jacuípe River, its main tributary (SILVA, 2012).

Ten river sections of these basins were considered, each corresponding to the selected dams. On these sections were included Baraúnas and Casa Branca dams, having their implantation projected for tributaries of the Paraguaçu River, but not constructed. All of the chosen dams are free sill. Among the dams from the Paraguaçu River, Pedra do Cavalo Dam was not included because its weir has floodgates, it has hydroelectric power generation, and is located in a more humid region. Figure 1 presents the location of Itapicuru and Paraguaçu rivers basins and the selected dams for the study, Figure 2 presents the schematic diagrams of the reservoir systems considered. Chart 1 presents the physical and operational data about the reservoirs in study.

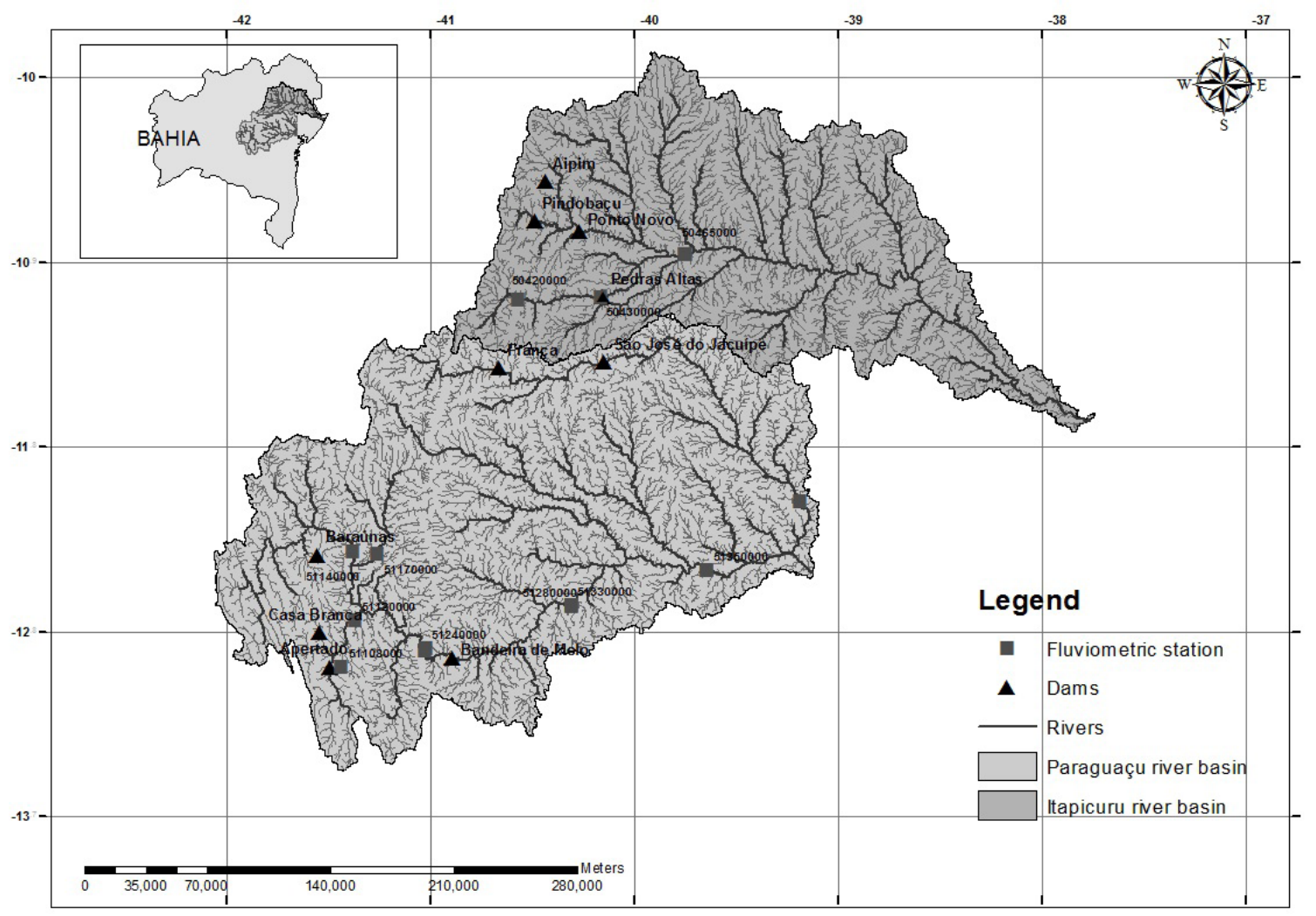

Figure 1. Location of the studied dams on the Itapicuru and Paraguaçu rivers basins. Source: Adapted from Inema (2014a). 

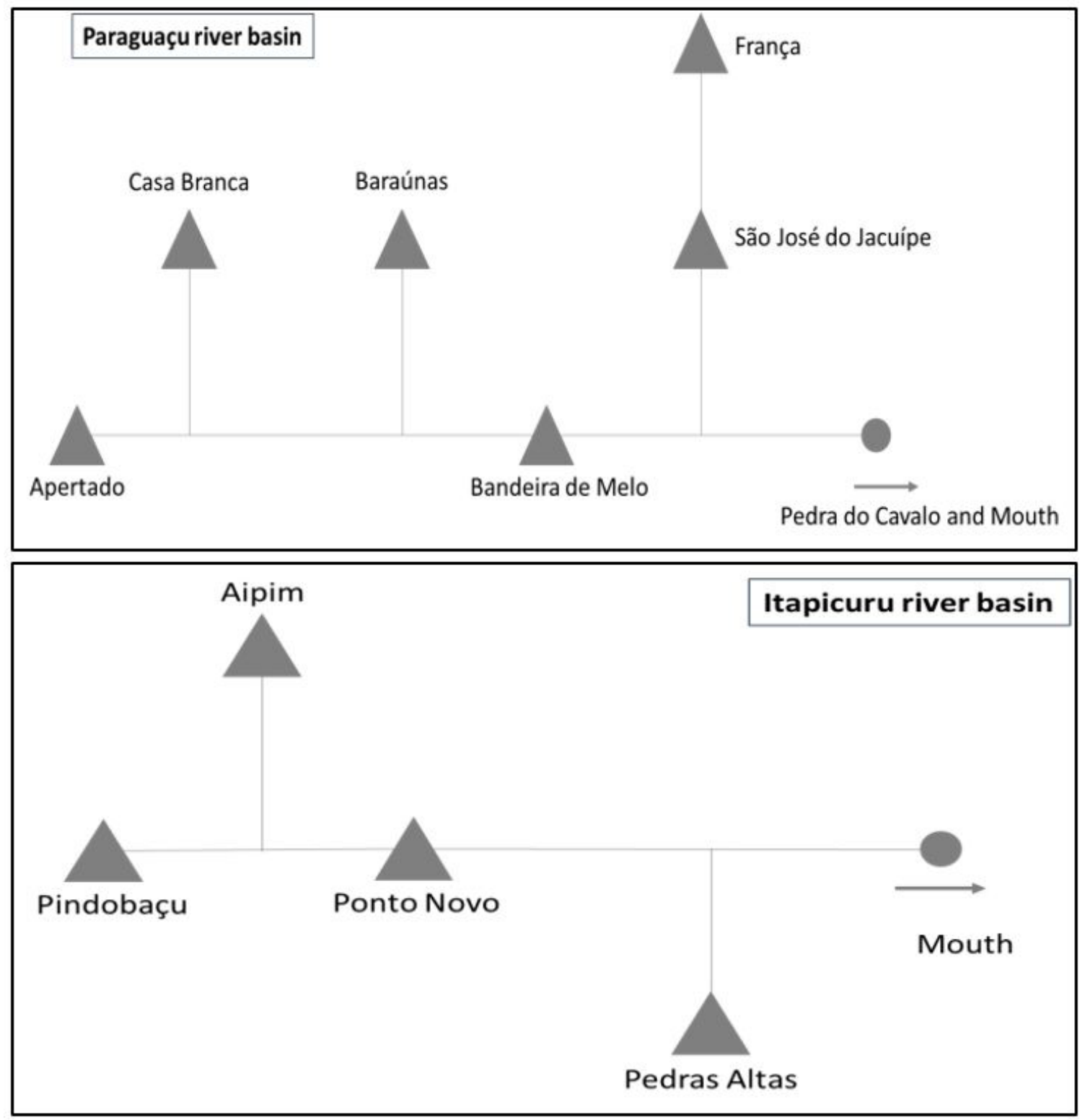

Figure 2. Single-line diagram of the reservoirs system of Paraguaçu and Itapicuru rivers basins.

Chart 1. Physical and operational data of the reservoirs in study.

\begin{tabular}{|c|c|c|c|c|c|c|c|c|}
\hline Watershed & Dam & $\begin{array}{c}\text { Maximum } \\
\text { height } \\
\text { (m) }\end{array}$ & $\begin{array}{c}\text { Cumulative } \\
\text { volume } \\
\left(\mathrm{hm}^{3}\right)\end{array}$ & \begin{tabular}{|c|} 
Regularized \\
flow \\
$\left(\mathrm{m}^{3} / \mathrm{s}\right)$
\end{tabular} & $\begin{array}{c}\text { Flood } \\
\text { area (ha) }\end{array}$ & $\begin{array}{c}\text { Watershed } \\
\text { area } \\
\left(\mathrm{km}^{2}\right)\end{array}$ & FUNCTION & $\begin{array}{c}\text { YEAR OF } \\
\text { INSTALLATION }\end{array}$ \\
\hline \multirow{4}{*}{ 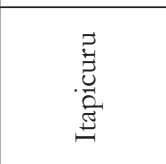 } & Aipim & 28.0 & 2.28 & 0.255 & 0.236 & 24.5 & HS & 1996 \\
\hline & Pedras Altas & 24.2 & 38.45 & 1.4 & 759.6 & $2,250.0$ & HS & 2002 \\
\hline & Pindobaçu & 44.0 & 16.8 & 1.89 & 232.0 & 605.0 & HS; IR & 2005 \\
\hline & Ponto Novo & 25.5 & 38.94 & 4.7 & $1,400.0$ & $2,400.0$ & HS; IR & 1999 \\
\hline \multirow{7}{*}{ 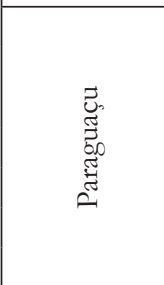 } & Apertado & 27.2 & 108.89 & 8.9 & $2,632.0$ & $1,166.0$ & HS; IR & 1998 \\
\hline & Bandeira de Melo & 19.1 & 111.59 & 18.83 & $2,087.0$ & $17,074.2$ & HS; IR & 2006 \\
\hline & Baraúnas & 16.5 & 39.0 & 1.21 & 347.0 & $1,624.0$ & HS; IR & - \\
\hline & Casa Branca & 12.0 & 22.37 & 0.81 & 440.0 & 139.4 & HS; IR & - \\
\hline & França & 25.5 & 24.19 & 0.39 & 497.4 & $2,030.0$ & HS & 1996 \\
\hline & Pedra do Cavalo & 125.0 & $4,630.0$ & 76.0 & $18,620.0$ & $53,860.0$ & HS; IR; PG; FC & 1985 \\
\hline & São José de Jacuípe & 41.0 & 357.0 & 1.9 & $2,635.0$ & $4,584.0$ & HS; IR & 1985 \\
\hline
\end{tabular}

Note: HS - Human Supply; IR - Irrigation; PG - Power Generation; FC - Flood Control. Source: Adapted from CERB (2004), CBDB (2004), Medeiros et al. (2004), BAHIA (2008). 


\section{METHODOLOGY}

In order to achieve the aims of this work, it was primarily necessary to generate river flow series without and with upstream control with views to characterize a non-impacted condition (reference) and an impacted condition, respectively, for the purpose of making possible an evaluation of the hydrologic alterations caused by the implantation of dams. The methology's order, after obtaining those series, involved: calculus of the hydrologic alteration indicators; classification of the hydrologic alteration through the original DHRAM's thresholds; adjustment of DHRAM's thresholds with local data; adjustment of DHRAM with regrouping of the statistical variables and resetting of thresholds; classification through DHRAM with both adjusted versions; and comparison between the classifications.

\section{Obtaining river flow series without and with upstream control}

To peform the analysis of impact of the hydrologic (flow) regime, the establishment of a non-impacted condition, or reference, and an impacted condition is necessary. Due to this necessity and on account of the absence of observed flow series on the river sections of interest (corresponding to the location of the dams) and in function of the fact that the data available from the fluviometric stations present a lot of flaws, simulated data series were used from previous studies for characterizing the flows without control upstream and, so, for representing the natural condition, that is, without the presence of dams, of the river sections that were evaluated. As for the flow series with control upstream, to represent the impacted condition by dams on those same sections, they were obtained through water allocation modeling.
The flow series without upstream control of the river sections considered were all obtained through the simulation of the Large-Basin Distributed Hydrological Model (MGB-IPH) performed within the Evaluation of Hydrologic Impact of Large Dams in the State of Bahia Networking Project - GRANBAR, for the data series referent to the Itapicuru River Watershed (FONTES et al., 2014). For the Paraguaçu River Watershed the flow series were generated along the execution of the Climate Change and Water Resources in Bahia project (GENZ et al., 2012). The MGB-IPH is a mathematical distributed rainfall-runoff model for application on large basins, that executes the processes of water balance in the soil; evapotranspiration; the flows: surface runoff, subsurface, and underground in cells and the flow on the drainage network in the entire watershed (COLLISCHONN et al., 2010). The model was calibrated based on historical data of periods before the influence of dams. In the simulation phase, the periods considered were of 1963-1991 for the Itapicuru River and of 1963-1990 for the Paraguaçu River.

The calibration of the model for the Paraguaçu River Basin considered six sub-basins defined by the fluviometric stations (GENZ et al., 2012), while for the Itapicuru River Basin only three were considered, selected accordingly to the extent of the series and the quality of the data (FONTES et al., 2014). Information about these fluviometric stations is presented in Chart 2.

The statistics used by Genz et al. (2012) and Cruz (2013) for the adjustment of the calibration of the hydrologic model for Paraguaçu and Itapicuru rivers sub-basins are presented in Table 1. For the evaluation of the adjustment, the Nash coefficient with calculated and observed flows $\left(\mathrm{R}^{2}\right.$, the modified Nash coefficient for the logarithm of flows $\left(\mathrm{R}^{2} \mathrm{Log}\right)$ and the difference between ccalculated and observed volumes $(\Delta \mathrm{V})$ were used. According to Genz et al. (2012), $\mathrm{R}^{2}$ and $\mathrm{R}^{2} \mathrm{Log}$ did not achieve expressive values, but the difference between the observed volume and the calculated volume was satisfactory, with the exception of Ponte Rio Branco station.

Chart 2. Fluviometric stations used for the hydrological modelling of Paraguaçu and Itapicuru rivers.

\begin{tabular}{|c|c|c|c|c|c|}
\hline Code & Name & River & Latitude & Longitude & Beneficiary river section \\
\hline 51140000 & Porto & Santo Antônio & -12.4911 & -41.3289 & Baraúnas \\
\hline 51170000 & Utinga & Utinga & -12.5008 & -41.2058 & -- \\
\hline 51240000 & Itaeté & Paraguaçu & -12.9928 & -40.9614 & Casa Branca and Apertado \\
\hline 51280000 & Iaçu & Paraguaçu & -12.7622 & -40.2136 & Bandeira de Melo \\
\hline 51350000 & Argoim & Paraguaçu & -12.5856 & -39.5222 & Pedra do Cavalo \\
\hline 51460000 & Ponte Rio Branco & Jacuípe & -12.2331 & -39.0461 & São José do Jacuípe and França \\
\hline 50465000 & Queimadas & Itapicuru & -10.9733 & -39.6328 & $\begin{array}{c}\text { Pedras Altas, Ponto Novo, Pindobaçu } \\
\text { and Aipim }\end{array}$ \\
\hline 50520000 & Ponte Euclides da Cunha & Itapicuru & -11.0603 & -38.8372 & -- \\
\hline 50540000 & Cipó & Itapicuru & -11.0983 & -38.5131 & -- \\
\hline
\end{tabular}

Source: Adapted from Genz et al. (2012), Fontes et al. (2014) and Cruz (2013).

Table 1. Statistics of the hydrologic modelling adjustment for the Paraguaçu and Itapicuru rivers watersheds.

\begin{tabular}{|c|c|c|c|c|c|c|c|c|c|}
\hline & Porto & Utinga & Itaeté & Iaçu & Argoim & $\begin{array}{l}\text { P. Rio } \\
\text { Branco }\end{array}$ & Queimadas & $\begin{array}{c}\text { Ponte } \\
\text { Euclides } \\
\text { da Cunha }\end{array}$ & Cipó \\
\hline $\mathrm{R}^{2} \mathrm{Nash}$ & 0.50 & 0.59 & 0.64 & 0.72 & 0.65 & 0.26 & 0.562 & 0.399 & 0.525 \\
\hline $\mathrm{R}^{2} \log$ & 0.53 & 0.53 & 0.65 & 0.66 & 0.67 & -0.04 & & & \\
\hline$\Delta \mathrm{V}[\%]$ & -2.8 & -0.2 & -0.8 & -4.2 & -7.5 & -30.4 & 0.38 & -12.3 & -13.25 \\
\hline
\end{tabular}

Source: Adapted from Genz et al. (2012), Fontes et al. (2014) and Cruz (2013). 
The calibration of the 3 sub-basins, located in the high and middle zones of the Itapicuru River Watershed, was made manually, obtaining the Nash coefficient with calculated and observed flows $\left(\mathrm{R}^{2}\right)$ and error of the total volumes (relative difference between the sum of all flows), with better adjustment for the station from Queimadas, considered in the present study.

For purposes of generating flow series with upstream control for the river sections in study, that represent the altered conditions caused by dams, it was used the Water Evaluation and Planning- WEAP21 (SEI, 2011) model. This model has optimization and simulation modules, it operates with the basic principle of the water balance and is applicable to sub-watersheds or complex river systems (SEI, 2011). After the assembly of typologies of each reservoir, the input data were inserted. The input flow data in this model were the series without upstream control obtained from the simulation with the MGB-IPH, so that the periods considered were the same for both conditions of simulation (without and with upstream control), excluding interference from climatic variation and the land use analysis. Besides the flows, initially, physical and operational data of the dams were also inserted: storage capacity, initial volume, dead volume, evaporation (calculated by the Penman-Monteith method), the demands and the remaining flows. The initial volume was considered as the maximum capacity of storage disregarding the influence of the reservoir filling period from the results.

Due to the difficulty of finding information referent to the demand of the reservoirs in study, it was opted for using the maximum granted demand for each reservoir in the modelling of the water system, based on the Superintendency of Water Resources Normative Instruction of Bahia (SRH) $\mathrm{N}^{\mathrm{o}} 01$, of February $27^{\text {th }}$ of 2007 . Thereby, for the consuming demand it was considered the limit of the sum of flows to be granted as $80 \%$ of regularized flows with $90 \%$ of assurance and for the minimum remaining flow, the remaining $20 \%$.

The set of priorities on the allocation of water consisted in: prioritizing the service of demanded flows (consumptive uses) and the remaining flow downstream in all periods of times. The maintenance of stored volumes in the reservoirs was a secondary priority. This set of priorities takes the system to the most critical scenario of service, inasmuch as the model must use the available water to meet the maximum possible of the withdrawals conceived flows at the same time it reserves water to meet the remaining flows.

\section{Obtaining the indicators of hydrologic alteration}

In order to identify the alterations resulting from dams, indicators of hydrologic alterion were used by applying the software the Indicators of Hydrologic Alteration -IHA (RICHTER et al., 1996). Those are calculated by means of the standard deviation among the time flow series without upstream control and with upstream control.

The IHA generates 33 statistical variables of ecological relevance (Chart 3 ) that are summarized in indicators to characterize the difference resulted after the implantation/operation of dams.

The IHA indicators are divided in 5 groups: Group 1: Magnitude of monthly water conditions; Group 2: Magnitude and duration of annual extreme water conditions; Group 3: Timing of annual extreme water conditions (maximum and minimum); Group 4: Frequency and duration of high and low pulses; Group 5: Rate/Frequency of water condition changes, rise/fall of flows.

In this work, IHA was applied in two situations: 1) using parametric analysis for application of the original DHRAM; 2) using non-parametric analysis for application of the DHRAM with adjustments, due to the fact that the series without upstream control used do not present a Normal distribution.

\section{Classification of the hydrologic regime alterations through the DHRAM with its original thresholds}

To proceed the classification of the alterations in the hydrological regime and to score the groups of impact for the area in analysis, it was applied the DHRAM method for all the dams selected in this study.

The DHRAM, for evaluating the degree of changes in the flow regime of the river, uses the average of the alteration factor calculated with the average values or the coefficient of variation of each IHA group of variables to attribute scores of impact.

Chart 3. IHA Variables.

\begin{tabular}{|c|c|}
\hline IHA Statistics Groups & Hydrologic Parameters \\
\hline Group 1: Magnitude of monthly water conditions & 1-12 Mean value for each calendar month. \\
\hline Group 2: Magnitude and duration of annual extreme water conditions & $\begin{array}{l}\text { 13-17 Annual minima flows for } 1,3,7,30 \text { and } 90 \text { days; } \\
\text { 17-22 Annual maxima flows for } 1,3,7,30 \text { and } 90 \text { days; } \\
23 \text { Number of zero-flow days; } \\
24 \text { 7-day minimum flow over mean for year (base flow). }\end{array}$ \\
\hline Group 3: Timing of annual extreme water conditions & $\begin{array}{l}25 \text { Julian date of each annual 1-day maximum; } \\
26 \text { Julian date of each annual 1-day minimum; }\end{array}$ \\
\hline Group 4: Frequency and duration of high and low pulses & $\begin{array}{l}27 \text { Number of high pulses/ flood events within each year; } \\
28 \text { Number of low pulses / dry events within each year; } \\
29 \text { Mean duration of high pulses within each year; } \\
30 \text { Mean duration of low pulses within each year; }\end{array}$ \\
\hline Group 5: Rate and frequency of water condition changes & $\begin{array}{l}31 \text { Means of all positive differences between consecutive daily values; } \\
32 \text { Means of all negative differences between consecutive daily values; } \\
33 \text { Number of hydrological reversals. }\end{array}$ \\
\hline
\end{tabular}

Source: Richter et al. (1997). 
For each group is obtained the values for the averages of the mean values (identified of $1 \mathrm{a}-5 \mathrm{a}$ ) and the coefficient of variation $(\mathrm{CV}$, identified of $1 \mathrm{~b}-5 \mathrm{~b})$ of their variables, so that there is a total of ten values synthesized to evaluate the degree of impact of dams in accordance to the lower, intermediate and upper thresholds presented in Chart 4.

The lower thresholds determine the limit in which that anthropic interferences do not cause risk of impact, in other words, above it these interferences start to present a risk for river ecosystems. The upper thresholds define the beginning of maximum impacts, from which the risk of impact to the ecosystem is high.

The positioning of the percentile values of alteration according to Chart 4 between the thresholds suggested by Black et al. (2005) resulted in an allocation of the scores of impact varying from 0 to 3 as presented in Chart 5.

Thereby, the sum of the obtained scores for the ten percentile values of synthesized chane defines the total score of impact. Chart 6 shows the ranges of scores considered by Black et al. (2005) to determine the expected degree of impact on the hydrologic regime. The maximum score of the method is 30 points.

After the points are counted for each group, they are summed to obtain a single value and this is the one used for the preliminary classification. Then, two questions must be answered:

- Do the sub-daily variations caused by human activities exceed $25 \%$ of flow with $95 \%$ duration of non-impacted flow?

- Do the anthropogenic impacts cause zero-flow?

For each positive answer, Black et al. (2005) recommend to add one more class to get a final classification.

\section{Adjustment of DHRAM's thresholds for the study area}

In order to make the adjustment of DHRAM's thresholds using local data, it was opted for following the procedure described by Black et al. (2005) for the upper and intermediate thresholds, and, altering the definition of the lower thresholds due to the existing data and the characteristic conditions of the places in study. So, the lower thresholds were defined considering the alteration of the natural variability by the confrontation of different periods of flow series without upstream control. Thus, values of alterations below that threshold would not represent an alteration caused by anthropic actions, but only a variability expected in conditions non-impacted by dams.

From ten river section/dams evaluated, 8 were selected for having their flow data as a means of help for that definition. The sections selected were: Aipim, Pindobaçu, Ponto Novo, Pedras Altas, Apertado, Bandeira de Melo, França and São José do Jacuípe. Baraúnas and Casa Branca were not inserted in this step, because they were not implemented yet.

Thereby, for the lower thresholds, the values obtained by the application of series without upstream control from IHA were used, reffering to the medians and coefficient of dispersion of the results of variables for the 5 categories, and the values of percentage change (or deviation factors) of each one of
Chart 4. Hydrologic alteration thresholds used to allocate the scores of impact.

\begin{tabular}{|c|c|c|c|c|}
\hline \multirow{2}{*}{$\begin{array}{c}\text { IHA } \\
\text { Variables }\end{array}$} & \multirow{2}{*}{$\begin{array}{c}\text { Synthesized } \\
\text { Indicators }\end{array}$} & \multicolumn{3}{|c|}{$\begin{array}{c}\text { \% mudança na pontuação do } \\
\text { grupo IHA }\end{array}$} \\
\cline { 3 - 5 } & & $\begin{array}{c}\text { Lower } \\
\text { Threshold }\end{array}$ & $\begin{array}{c}\text { Intermediate } \\
\text { Threshold }\end{array}$ & $\begin{array}{c}\text { Upper } \\
\text { Threshold }\end{array}$ \\
\hline \multirow{2}{*}{ Group 1 } & 1a & 19.9 & 43.7 & 67.5 \\
\cline { 2 - 5 } & 1b & 29.4 & 97.6 & 165.7 \\
\hline \multirow{2}{*}{ Group 2 } & 2a & 42.9 & 88.2 & 133.4 \\
\cline { 2 - 5 } & 2b & 84.5 & 122.7 & 160.8 \\
\hline \multirow{2}{*}{ Group 3 } & $3 \mathrm{a}$ & 7 & 21.2 & 35.5 \\
\cline { 2 - 5 } & $3 \mathrm{~b}$ & 33.4 & 50.3 & 67.3 \\
\hline \multirow{2}{*}{ Group 4 } & $4 \mathrm{a}$ & 36.4 & 65.1 & 93.8 \\
\cline { 2 - 5 } & 4b & 30.5 & 76.1 & 121.6 \\
\hline \multirow{2}{*}{ Group5 } & $5 \mathrm{a}$ & 46 & 82.7 & 119.4 \\
\cline { 2 - 5 } & 5b & 49.1 & 79.9 & 110.6 \\
\hline
\end{tabular}

Source: Black et al. (2005).

Chart 5. Scores of impact related to the percentage thresholds of alteration.

\begin{tabular}{|c|c|}
\hline Scores of impact & Thresholds of alteration \\
\hline 0 & $<$ lower threshold \\
\hline 1 & $\begin{array}{c}\geq \text { lower threshold and } \\
<\text { intermediate threshold }\end{array}$ \\
\hline 2 & $\begin{array}{c}\geq \text { intermediate threshold and } \\
<\text { upper threshold }\end{array}$ \\
\hline 3 & $\geq$ upper threshold \\
\hline
\end{tabular}

Source: Black et al. (2005).

Chart 6. Classification of hydrologic alterations.

\begin{tabular}{|c|c|l|}
\hline Class & $\begin{array}{c}\text { Class } \\
\text { interval }\end{array}$ & \multicolumn{1}{c|}{ Description } \\
\hline 1 & 0 & No alteration (non-impacted condition) \\
\hline 2 & 1 to 4 & Low risk of impact \\
\hline 3 & 5 to 10 & Moderate risk of impact \\
\hline 4 & 11 to 20 & High risk of impact \\
\hline 5 & 21 to 30 & Severely impacted condition \\
\hline
\end{tabular}

Source: Black et al. (2005).

the variables. Having these data, the means and the standard deviation of the medians and of the coefficients of dispersion were calculated. The coefficients of dispersion are calculated by the non-parametric approach through IHA as the difference between the $75^{\text {th }}$ percentile and the $25^{\text {th }}$ percentile, over the $50^{\text {th }}$ percentile (TNC, 2009). The values for the mean and the coefficient of dispersion were obtained for the variables of the 5 categories for the 8 river sections. The resulting values of the summing of means and the stardad deviation for each one of the groups of the selected sections consisted in new thresholds for each group.

For the upper references, described by the authors as essential for the establishment of intermediate thresholds, following Black et al. (2005), among the 10 dams evaluated the biggest alterations were assumed using the results of IHA derived from the comparison between the non-impacted condition and the impacted condition, in other words, the confrontation of the flow series without and with upstream control. 
On the other hand, the intermediate thresholds were defined using the distance between the lower threshold and the upper reference divided by three. This result consisted in the intervals between the thresholds.

Thus, for each one of the 5 groups, it was established a reference threshold value referring to the central tendency measure (identified with letter a) and the other referring to the dispersion measure (identified with letter b), the result of the summing of means and the standard deviation and the coefficients of dispersion of the 5 groups.

\section{Adjustment of the DHRAM with regrouping the IHA groups and resetting the thresholds}

Aiming a more detailed representation of the studied sections from the behavior of the statistical variables, adjustments were proposed to the DHRAM method that focused on aspects of:

1. Reorganization of the IHA groups for synthesizing the indicators.

2. Definition of new thresholds to attribute the points of impacts based on the characteristics of the flow series of the river sections selected for the study and new reorganization of statistical variables;

3. Evaluation of the degree of impact of dams to the level of the sub-groups suggested.
The reorganization of the variables within the 5 IHA groups was motivated as a means of improvement to represent semi-arid hydrology.

To substantiate this reorganization, the Friedman Test was done for groups that have 3 or more variables and the Wilcoxon Test was applied for the groups with two variables in order to get suggestions of new groupings of variables. The tests were done through the IBM SPSS Statistics 19 statistical package.

In the tests, the variables were analyzed starting from the groupings already set by the IHA to indicate the similarity between them. These variables were separated according to the result of the ranks and the outcome percentiles, as also the observed significance (greater or less than 0.05).

From the comparison of two variables, when the test pointed to inequality, they were separated and each began to form a new group, denominated sub-group of the IHA initial group.

Having the sub-groups defined, the procedure of adjustment of thresholds was reapplied considering the results of IHA.

The application of the method with adjustment used all 10 sections in study, following the procedure shown in Figure 3.

\section{Comparison of the classification of alteration and evaluation of the proposed adjustments}

After applying DHRAM in three versions: considering the thresholds that define the scores for the classification of impact on its original set (according BLACK et al., 2005); adjusting

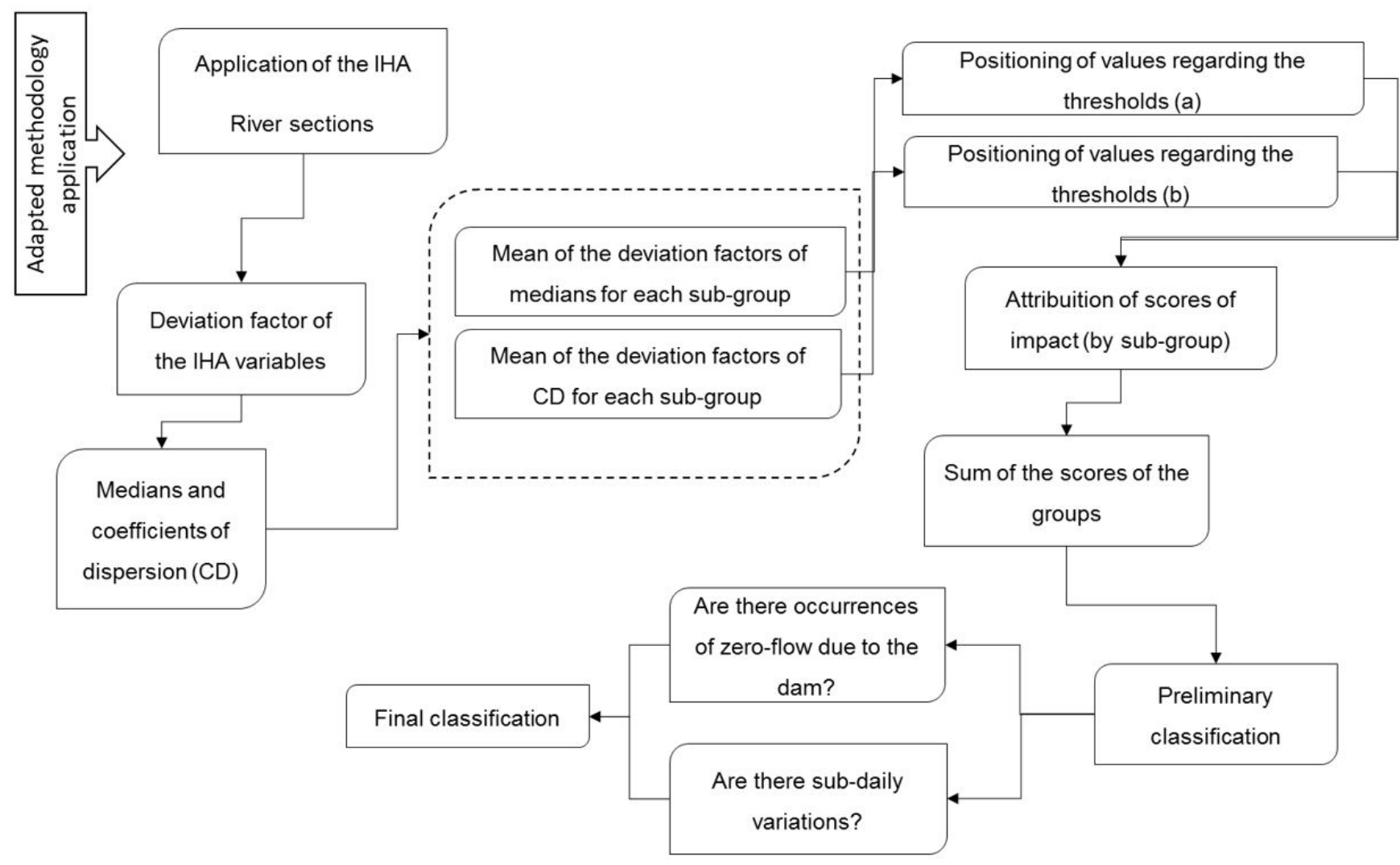

Figure 3. Procedure to apply the methodology of the DHRAM classification with adjustment. 
those thresholds to local conditions; and regrouping the variables and adjusting the thresholds, proceeded the comparison of the results to verify the adherence of the methodology to the peculiar regions studied.

It was also made a comparison of the results of this work with results obtained in previous studies that evaluated the hydrologic alteration of the studied river sections, as it was applied the DHRAM method with adjustment using measured flow data from 2007 to 2015 on Pedras Altas and Bandeira de Melo sections, that present data of upstream and downstream of the dam.

\section{RESULTS AND DISCUSSION}

\section{Comparison of simulated flow series without and with upstream control}

Using flow series without upstream control and with upstream control obtained for the ten river sections from the simulation of hydrologic models made possible to observe the resulting transformations on the hydrologic regime in function of the presence of dams. For such, scatter charts were plotted to compare both series (Figure 4) that illustrate in a joint form the alterations that happened on the sections. For example, the sections of Bandeira de Melo and São José do Jacuípe are highlighted for presenting the lowest and the highest alterations of the flow, respectively.

In general, when comparing series without and with upstream control, it is noted that the flow was reduced due to the presence of dams as the points of the scatter chart approach the abscissa axis (zero-flow), or they are deviating from the bisectrix (equal values). This happens predominantly for the lower values of flow. For the peak flows, there is a trend of maintaining the same magnitude without any significant cushioning in flood events.

The difference between the hydrograms considering the flows without and with upstream control for Bandeira de Melo and São José do Jacuípe is presented in Figure 5.

Figure 5 enables to identify that the river section referring to Bandeira de Melo dam presented alterations with small difference in magnitude and seasonality of flows. On the other hand, it is shown that for São José do Jacuípe section the presence of the dam represented a more highlighted regulation.

\section{Application of the DHRAM with its original thresholds}

The classification of impact caused by each dam over the hydrologic regime derives from the results of the application of the IHA, using parametric analysis, being used the values of deviation of the hydrologic flow variables without upstream control and with upstream control (between non-impacted and impacted condition), resulting the classification displayed in Table 2, obtained applying the thresholds presented in Black et al. (2005).

Bandeira de Melo and Aipim were the sections that exhibited the lowest alterations of the flow regime. Such sections were classified as Class 3 (moderate impact on the river system), but their scores were very near the maximum attributed to Class

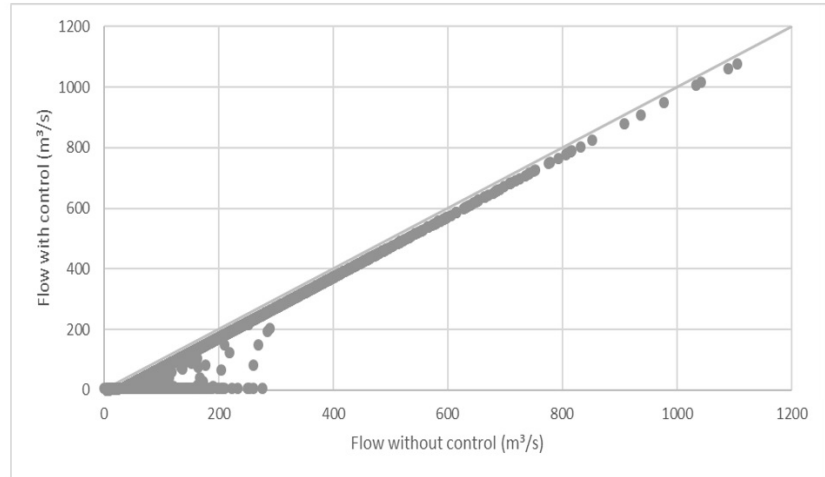

(a)

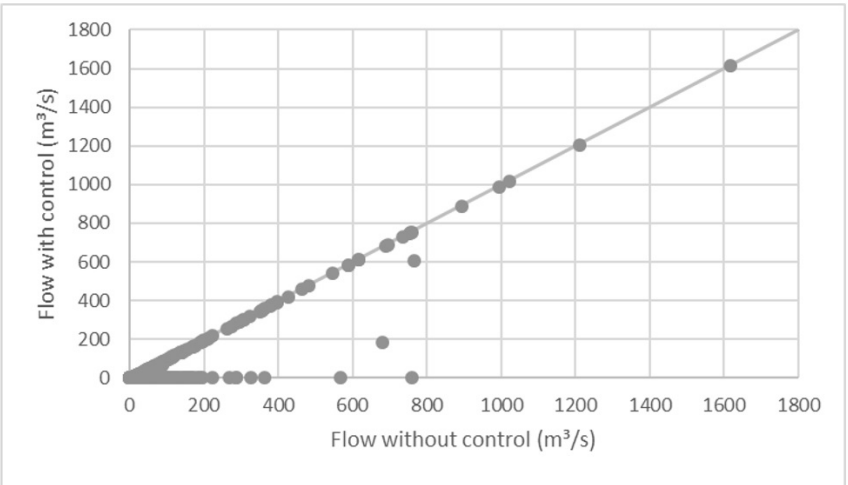

(b)

Figure 4. Behavior of the dispersion of flow series without upstream control vs. with upstream control for Bandeira de Melo (a) and São José do Jacuípe (b).

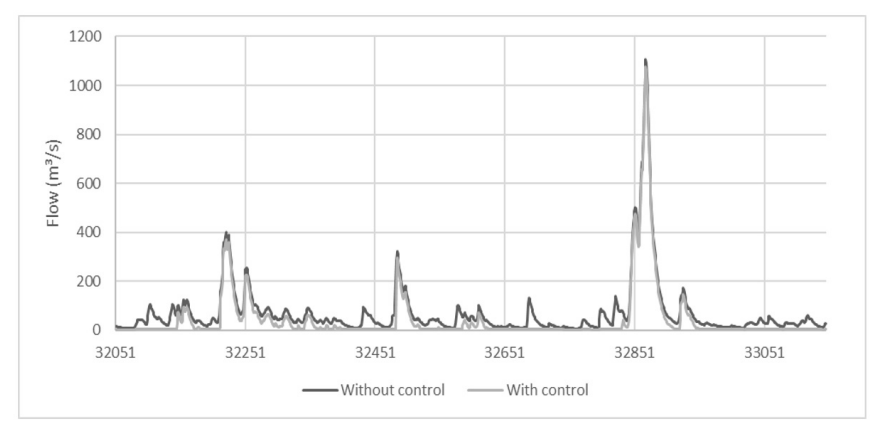

(a)

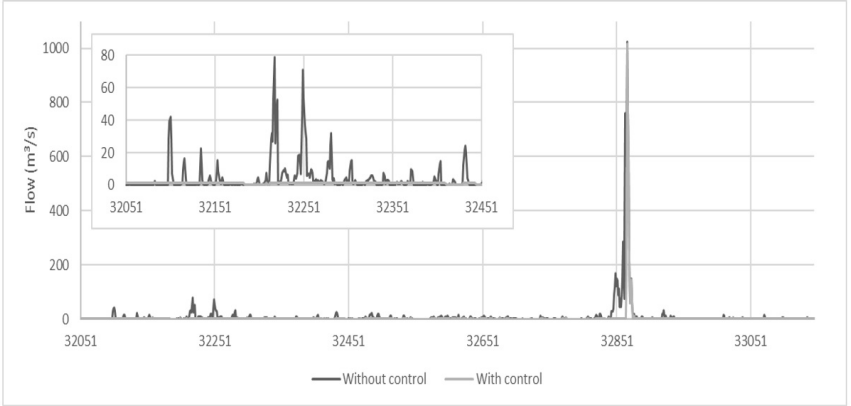

(b)

Figure 5. Comparison of flows without upstream control and with upstream control for Bandeira de Melo (a) and São José do Jacuípe (b) sections. 
2 (low impact on the river system). Because Bandeira de Melo is not a dam that has a storage tank, it does not impose significant alteration in the frequency of flows, cushioning only the higher flows and regularizing the lower flows. Also it was possible to identify that Pindobaçu and Ponto Novo sections got scores near Class 3.

In reference of São José do Jacuípe section, meeting the demands and storing water to increase local availability provoke serious modifications of the flows downstream the section (Figure 5b). Fontes et al. (2005) indicate the inefficiency of this dam regarding the regulation of flow influenced by the reservoir geometry and evaporation rates. Furthermore, the authors concluded that the reservoir is oversized. This section refers to the largest dam studied here in terms of drainage area and storage capacity, getting a classification of severe impact (Table 2), which corresponds to the physical characteristics and operational conditions simulated and shows adequacy of the method on representing the section.

In view of the observed, it is considerable that the DHRAM succeeded at representing the alterations imposed to the flow series due to the implantation of dams and the known characteristics (storage capacity, drainage area and type of the weir) for part of the river sections. Still, to deepen the evaluation of the classification method of hydrologic alterations, the application of the DHRAM with the proposed adjustments proceeded.

\section{Application of the DHRAM with adjustments}

\section{Test for the adjustment of thresholds}

The first attempt of adjustment of the DHRAM referred only to the definition of new thresholds used to attribute scores of impact. These new thresholds were calculated based on the flow series that were simulated for the river sections of the selected dams, applied in IHA with a non-parametric approach. The new thresholds are presented in Chart 7, resulting on the classification of dams exhibited in Table 3.

By comparing the adjusted thresholds with the original ones from DHRAM, it is noted that, except the lower limits of group 2a, all of the thresholds present bigger values with the adjustment. The high values of group 2 thresholds result from the minimum flows with upstream control, expressively bigger than the ones of its natural state when they reached values near to zero. Such behavior is observed on the dam sections of the Jacuípe
River (França and São José do Jacuípe), that have regime different from the other rivers. After analyzing the relevance to consider these dams in the process of the classification adjustment, it was opter for keeping them in the analysis because they contemplate scenarios present on intermittent rivers.

Thereby, the adjustment made the attributed ranges of impact to be expanded, increasing the interval of score for "no" impact (score 0 ) and also elevating the upper limit for the attribution of the highest score of impact (score 3). Thus, the adjusted thresholds revealed to be less restrictive, making more possibilities for scores

Table 2. Results of the classification of the degree of impact of dams using the DHRAM classification method with its original thresholds.

\begin{tabular}{lccc}
\hline \multicolumn{1}{c}{ Dams } & $\begin{array}{c}\text { Final } \\
\text { Score }\end{array}$ & $\begin{array}{c}\text { Partial } \\
\text { Classification }\end{array}$ & $\begin{array}{c}\text { Final } \\
\text { Classification }\end{array}$ \\
\hline Aipim & 6 & Moderate & Moderate \\
Pedras Altas & 18 & High & High \\
Pindobaçu & 12 & High & High \\
Ponto Novo & 12 & High & High \\
Apertado & 15 & High & High \\
Bandeira de & 6 & Moderate & Moderate \\
Melo & & & \\
Baraúnas & 15 & High & High \\
Casa Branca & 18 & High & High \\
França & 19 & High & Severe \\
São José do & 21 & Severe & Severe \\
Jacuípe & & & \\
\hline
\end{tabular}

Table 3. Classification of the alterations with the adjustment of thresholds.

\begin{tabular}{ccc}
\hline Dams & Final Score & Classification \\
\hline Aipim & 4 & Low \\
Pedras Altas & 9 & High \\
Pindobaçu & 7 & Moderate \\
Ponto Novo & 3 & Low \\
Apertado & 9 & Moderate \\
Bandeira de Melo & 5 & Moderate \\
Baraúnas & 6 & Moderate \\
Casa Branca & 7 & Moderate \\
França & 8 & Moderate \\
São José do Jacuípe & 9 & Moderate \\
\hline
\end{tabular}

Chart 7. DHRAM's thresholds for the attribution of scores of impact caused by dams based on local data.

\begin{tabular}{|c|c|c|c|c|c|c|}
\hline \multicolumn{2}{|c|}{ Group } & Lower Thresholds & $\begin{array}{c}\text { Intermediate } \\
\text { Thresholds }\end{array}$ & Uper Thresholds & Uper Reference & Interval \\
\hline \multirow{2}{*}{ Group 1} & $1 \mathrm{a}$ & 54.21 & 300.43 & 546.66 & 792.89 & 246.23 \\
\hline & $1 \mathrm{~b}$ & 157.59 & 215.85 & 274.11 & 332.36 & 58.26 \\
\hline \multirow{2}{*}{ Group 2} & $2 \mathrm{a}$ & 33.37 & 7143.20 & 14253.03 & 21362.87 & 7109.83 \\
\hline & $2 \mathrm{~b}$ & 116.56 & 5515.86 & 10915.16 & 16314.46 & 5399.30 \\
\hline \multirow{2}{*}{ Group 3} & $3 a$ & 119.33 & 423.03 & 726.73 & 1030.43 & 303.70 \\
\hline & $3 \mathrm{~b}$ & 80.62 & 90.59 & 100.55 & 110.51 & 9.96 \\
\hline \multirow{2}{*}{ Group 4} & $4 a$ & 43.91 & 362.42 & 680.94 & 999.46 & 318.52 \\
\hline & $4 \mathrm{~b}$ & 86.44 & 255.73 & 425.01 & 594.29 & 169.28 \\
\hline \multirow{2}{*}{ Group 5} & $5 \mathrm{a}$ & 31.18 & 97.28 & 163.38 & 229.48 & 66.10 \\
\hline & $5 c$ & 68.65 & 681.97 & 1295.29 & 1908.60 & 613.32 \\
\hline
\end{tabular}


between the ranges of 1 and 2 points. This can be justified by the high natural variability present in semi-arid rivers.

It is seen in Table 3 that, with the exception of Bandeira de Melo and Pedras Altas, the classification of impact on the hydrologic regime for the other dams differs from the classification using the original thresholds.

For Aipim, the resulting classification of low impact with the adjustment of thresholds can be expected due to its low storage capacity and its small drainage area. However, for São José do Jacuípe, the outcome did not represent the situation of impact expected for the local characteristics described previously.

In view of the results of the classification of impact of dams applying the DHRAM only with the adjustment of thresholds and being identified classifications that are still less representative for some of the dams, adjustments were made concerning the groupings of the statistical variables considered by the method. Thus, the regrouping of variables was proceeded aiming to improve the representativeness of the final classification of the dams.

\section{Regrouping the variables and defining new thresholds}

The grouping of variables used for the attribution of points and the definition of limits of the classification method of impacts caused by dams was based on the similarity between them, indicated by the statistical analysis employing the Wilcoxon and Friedman tests at a significance level of 5\%. The statistical differences more relevant were between the maximum and minimum flows behavior (Group 2) and between the mean flow of the driest months in the region (August to October) and the other months (Group 1). This result reassures the peculiar characteristics of the hydrology in semi-arid of Bahia.

The variables were rearranged in 12 groups that are presented in Chart 8.

Table 4 displays the thresholds defined with the use of non-parametric analysis, considering the regrouping of the IHA variables. In Table 4 the items identified with letter $a$ refer to the medians values and those identified with letter $b$ to the coefficient of dispersion.

It is worth highlighting that the IHA results for Group 3 considered the order of days of the Julian year to compute the variation observed on the days when occurred extreme events (maximum and minimum flow). In case this occurrence happens in December and January, the indicators numerically evidence a high degree of alteration, although the hydrologic alteration is not characterized. The study area presents this behavior for flood flows with extreme events at the end/beginning of the year. Due to the verification of this inconsistency, it was opted for disregarding Group 3 on the step of application of the DHRAM with adjustment and, hence, on the classification of the degree of impact of dams.

Table 4. DHRAM thresholds to attribute scores of impact caused by dams based on local data and the regrouping of variables.

\begin{tabular}{|c|c|c|c|c|c|}
\hline \multicolumn{3}{|c|}{ Group } & \multirow{2}{*}{$\begin{array}{c}\text { Lower } \\
\text { Thresholds }\end{array}$} & \multirow{2}{*}{$\begin{array}{l}\text { Intermediate } \\
\text { Thresholds }\end{array}$} & \multirow{2}{*}{$\begin{array}{c}\text { Upper } \\
\text { Thresholds }\end{array}$} \\
\hline $\begin{array}{c}\text { IHA } \\
\text { Groups }\end{array}$ & & $\begin{array}{l}\text { Sub- } \\
\text { roups }\end{array}$ & & & \\
\hline \multirow{4}{*}{ Group 1} & \multirow{2}{*}{1} & $1.1 \mathrm{a}$ & 53.48 & 120.63 & 187.78 \\
\hline & & $1.1 \mathrm{~b}$ & 167.75 & 232.54 & 297.33 \\
\hline & \multirow{2}{*}{2} & $1.1 \mathrm{a}$ & 36.71 & 443.00 & 849.29 \\
\hline & & $1.1 \mathrm{~b}$ & 148.69 & 203.30 & 257.90 \\
\hline \multirow{4}{*}{ Group 2} & \multirow{2}{*}{1} & $2.1 \mathrm{a}$ & 31.50 & 11012.18 & 21992.86 \\
\hline & & $2.1 \mathrm{~b}$ & 52.24 & 8917.32 & 17782.40 \\
\hline & \multirow{2}{*}{2} & $2.2 \mathrm{a}$ & 23.95 & 53.88 & 83.81 \\
\hline & & $2.2 \mathrm{~b}$ & 123.75 & 1296.52 & 2469.28 \\
\hline \multirow{4}{*}{ Group 3} & \multirow{2}{*}{1} & $3.1 \mathrm{a}$ & 12.16 & 12.66 & 13.16 \\
\hline & & $3.1 \mathrm{~b}$ & 45.70 & 63.80 & 81.90 \\
\hline & \multirow{2}{*}{2} & $3.2 \mathrm{a}$ & 25.75 & 301.93 & 578.11 \\
\hline & & $3.2 \mathrm{~b}$ & 29.43 & 52.95 & 76.48 \\
\hline \multirow{6}{*}{ Group 4} & \multirow{2}{*}{1} & $4.1 \mathrm{a}$ & 34.67 & 356.26 & 677.86 \\
\hline & & $4.1 \mathrm{~b}$ & 56.19 & 209.42 & 362.65 \\
\hline & \multirow{2}{*}{2} & $4.2 \mathrm{a}$ & 29.24 & 456.75 & 884.26 \\
\hline & & $4.2 \mathrm{~b}$ & 30.19 & 211.50 & 392.80 \\
\hline & \multirow{2}{*}{3} & $4.3 \mathrm{a}$ & 14.23 & 27.26 & 40.30 \\
\hline & & $4.3 \mathrm{~b}$ & 25.04 & 87.07 & 149.09 \\
\hline \multirow{6}{*}{ Group 5} & \multirow{2}{*}{1} & $5.1 \mathrm{a}$ & 14.14 & 61.39 & 108.64 \\
\hline & & $5.1 \mathrm{~b}$ & 40.05 & 643.38 & 1246.70 \\
\hline & \multirow{2}{*}{2} & $5.2 \mathrm{a}$ & 22.92 & 160.14 & 297.37 \\
\hline & & $5.2 \mathrm{~b}$ & 20.73 & 784.93 & 1549.14 \\
\hline & \multirow{2}{*}{3} & $5,3 \mathrm{a}$ & 9.06 & 37.84 & 66.62 \\
\hline & & $5,3 \mathrm{~b}$ & 40.94 & 717.83 & 1394.73 \\
\hline
\end{tabular}

Chart 8. Regroupings of the IHA variables.

\begin{tabular}{|c|c|c|}
\hline Group IHA & Sub-group & IHA Variables \\
\hline \multirow{2}{*}{1} & 1 & Monthly mean flow from November to July (Qnov, Qdec, Qjan, Qfeb, Qmar, Qapr, Qmay, Qjun, Qjul) \\
\hline & 2 & Monthly mean flow from August to October (Qaug, Qsep, Qoct) \\
\hline \multirow{2}{*}{2} & 1 & $\begin{array}{l}\text { Minimum flow with duration of } 1 \text { to } 30 \text { days and baseflow index (Qmin1, Qmin3, Qmin7, Qmin30 and } \\
\text { baseflow) }\end{array}$ \\
\hline & 2 & $\begin{array}{l}\text { Maximum flow with duration of } 1 \text { to } 90 \text { days and minimum flow with duration of } 90 \text { days (Qmin90, } \\
\text { Qmáx1, Qmáx3, Qmáx7, Qmáx30, Qmáx90) }\end{array}$ \\
\hline \multirow{2}{*}{3} & 1 & Julian date of each annual 1-day maximum \\
\hline & 2 & Julian date of each annual 1-day minimum \\
\hline \multirow{3}{*}{4} & 1 & Number of high and low pulses/ flood and dry events within each year \\
\hline & 2 & Mean duration of high pulses within each year \\
\hline & 3 & Mean duration of low pulses within each year \\
\hline \multirow{3}{*}{5} & 1 & Means of all positive differences between consecutive daily values \\
\hline & 2 & Means of all negative differences between consecutive daily values \\
\hline & 3 & Number of hydrological reversals \\
\hline
\end{tabular}


With the regrouping of variables and the removal of Group 3 for the attribution of scores of impact, the possible total sum of points of the adjusted method became 60 , double the total of the original one, and the ranges for scoring and classifying were also multiplied by two. The outcome of this adjustment is presented in Chart 9.

The classification of impact provoked by each dam over the hydrologic regime using the DHRAM with this adjustment is presented in Table 5 .

From Table 5, it is observed that for five dams the classification indicated a moderate risk of impact (Pindobaçu, Ponto Novo, Apertado, Casa Branca e França). For Aipim, Bandeira de Melo and Baraúnas the impact was classified as low and for Pedras Altas and São José do Jacuípe as high impact on the hydrologic regime.

In general, Groups 2, 4 and 5, that refer, respectively, to the magnitude and duration of annual extreme water conditions, frequency and duration of droughts and floods, and rates and frequency of changes in flows, were the ones that presented higher alterations against the operation of reservoirs, receiving higher scores (Group 5 got the highest score in 9 dams) and, so, influencing directy on the classification obtained for the dams. Soares et al. (2015) and Fiuza et al. (2014) in their evaluations also indicated variables related to these groups as being the most relevant ones for their results. Group 1 (magnitude of monthly flows) was the one that presented the lowest alterations. Aipim, França, São José indicated higher alteration of flows on the months of August, September and October, and Apertado, Baraúnas in November to July.

Analyzing the sub-groups of the groups that highlighted the most on the attribution of scores outcome the following:

- Group 2, the sub-group that gathered the variables relating to the maximum flows obtained the highest scores and, hence, the highest alterations, mainly in Apertado and Casa Branca.

- Group 4, the sub-group that indicated the highest alterations was related to the duration of droughts, presenting higher scores for Aipim, Pedras Altas, Pindobaçu, Ponto Novo and Apertado.

- Group 5, the indicator of the "number of reversals" received the highest score for 9 dams.

The results for the classification of the degree of impact regarding Bandeira de Melo and Pedras Altas are comparable to the evaluation of hydrologic alterations caused by those dams in the study of Santos et al. (2015), showing that such results are similar.

Chart 9. Classification ranges - adapted DHRAM.

\begin{tabular}{|c|c|c|}
\hline Class & $\begin{array}{c}\text { Class } \\
\text { interval }\end{array}$ & Description \\
\hline 1 & 0 & No alteration (non-impacted condition) \\
\hline 2 & 1 to 8 & Low risk of impact \\
\hline 3 & 9 to 20 & Moderate risk of impact \\
\hline 4 & 21 to 40 & High risk of impact \\
\hline 5 & 41 to 60 & Severely impacted condition \\
\hline
\end{tabular}

The low alteration on the hydrologic regime obtained for Bandeira de Melo, in this study, is similar to the result from Santos et al. (2015), that characterized the hydrologic alterations due to the presence of Bandeira de Melo and Pedras Altas, using historical series from fluviometric stations located upstream and downstream them. These authors evidenced that the presence of Bandeira de Melo grants less relevant alterations to the hydrologic regime on the section downstream, being conserved mainly the seasonality. For Pedras Altas, Santos et al. (2015) observed significant alteration on the hydrologic regime downstream the dam. According the authors, this dam has a great capacity of regulation, causing the increase of minimum flow in a major part of the period in study. In the classification developed in the present study, this dam was defined as a high impact provocateur for the river system.

From the results in Table 5, the classification of São José do Jacuípe dam changed to high and is accordingly to Fontes et al. (2005) regarding the inefficiency of its reservoir. In relation to Ponto Novo, the classification indicated a moderate impact on the river system, approaching the physical and operational characteristics of the dam. This dam has relevant storage capacity providing flow regulation and imposing hydrologic regime alterations.

Aiming to evaluate the results obtained from the application of the method with adjustment, the classification also proceeded for Pedras Altas and Bandeira de Melo using observed data simultaneously in fluviometric stations positioned upstream and downstream those dams. For Bandeira de Melo, the data from fluviometric stations 51240000 and 51280000 were used to apply in the IHA within the period of 2007 to 2015; for Pedras Altas, the stations were 50420000 and 50430000 for the same period as the first.

It was noted that the results found for the dams using the observed data are equal the results from the application based on the simulated data. These results indicate representativeness of the simulated series and an adequate adherence of the method with the regrouping of variables and adjustment of thresholds to the characteristics of the study area, confirming the results obtained.

Comparing the classifications obtained with the original method and the one with the reorganization of variables and the adjustment of thresholds, it is noted that both approached the characteristics of the dams. Such characteristics, already presented, are not only identified by the observation of the state of some dams regarding their storage and pouring, but as also considering the cases that there are records of upstream and downstream flows (that made possible the evaluation of the results of the application of the DHRAM with adjustment and use of simulated flow series).

In light of the analysis of results of DHRAM's application, it was identified that the final classification of dams can be complemented with an evaluation of the alterations of the hydrologic aspects gathered in the sub-groups, enriching the aid for the water management and planning in the watersheds studied. So, the explicitness of the scores of impact attributed and the evaluation of the occurred hydrologic alterations in each sub-group can present indicators to help the decision-making process. This aid comes in the sense of evidencing the aspects that deserve more attention and that can be altered from changes in the operating rules of the reservoirs (operating levels, minimum remaining flows 


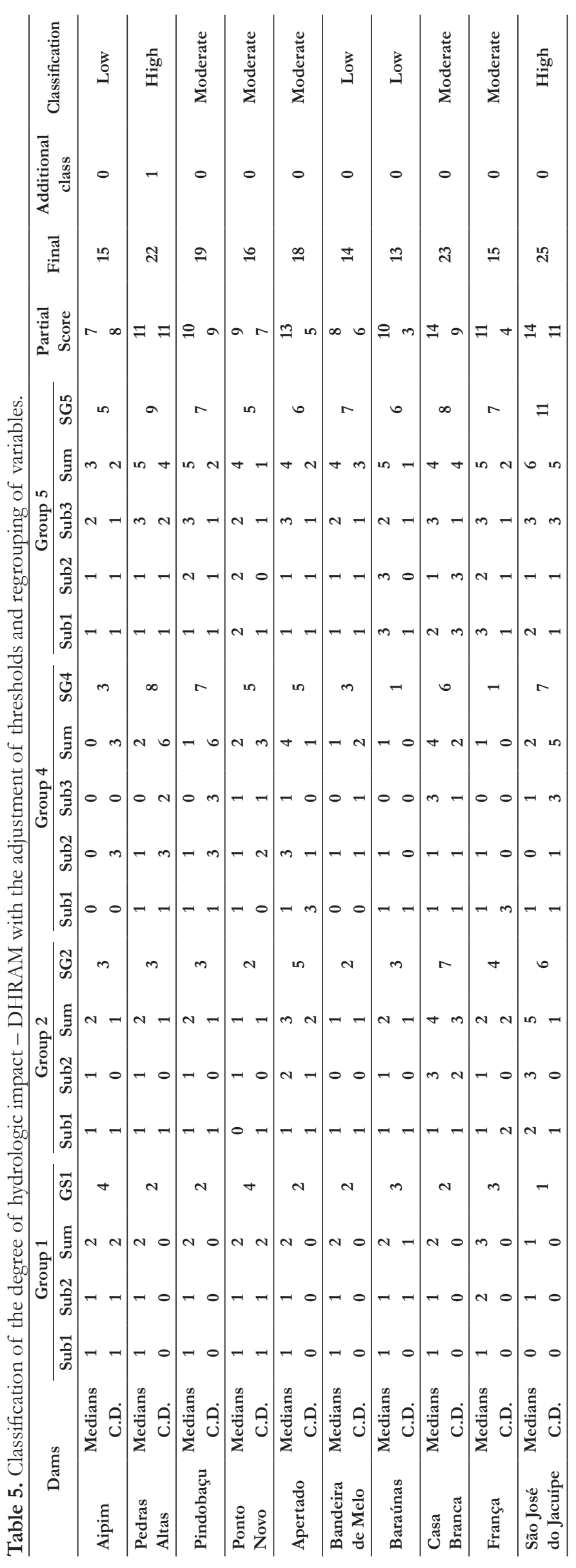


with seasonal behavior, definition of storage priorities) for dams that have already been implanted and also in the characteristics of new projects (implantation site, type of weir, bottom discharge).

Thereby, the application presented positive results, highlighting the definition of new thresholds with data from the studied regions; and the regrouping of variables expanded the representativeness of the results for the watersheds in study.

\section{CONCLUSIONS}

Original DHRAM results from its application were presented, having adjusted the thresholds with local data and adjusted the thresholds associated to the regrouping of variables. Such results allowed to achieve the aim of this work of evaluating the application of the DHRAM in the Itapicuru and Paraguaçu rivers as well as their tributaries verifying the adequacy of its use for representing the characteristics of semi-arid rivers. So, from the results it was concluded that:

- The results referring to the original version of DHRAM showed that its application should be developed with caution, as it tends to increase the degree of impact of dams in relation to the adjusted version considering the regrouping of variables. This behavior demonstrates more limitation regarding the high hydrological variability which is a natural characteristic of semi-arid rivers.

- The version of the method which had just the adjustment of the thresholds flexibilized the score ranges of impact, making the classification less restrictive, but it did not succeed on representing the characteristics of all the sections studied.

- The adjustment of the methodology applied on the original DHRAM regarding the thresholds and the reorganization of the variables resulted in a closer classification of the characteristics of the dams. The representation of those characteristics from this adjustment was reassured by results from previous studies and application using flow data measured upstream and downstream.

- The DHRAM method was revealed as an useful tool to evaluate the potential impact of dams still in project, like the studied cases of Baraúnas and Casa Branca, whose expected outcome is low and moderate risk of impact, respectively.

- For the dams already implanted, the results from the DHRAM application can guide the adoption of operating rules that minimize the most significant hydrologic alterations.

- It was identified that the response of the hydrological impacts caused by dams can be complemented with an analysis of the alterations occurred on the hydrologic variables gathered in the subgroups, enriching the contribution for the management and planning of water resources in watersheds, by giving more specific information on the most affected variables.

- Regarding to the alterations for the timing of annual one-day extreme flow (Group 3), the way they are computed by the
IHA is inadequate for hydrologic regimes with extreme events that occur around the end and beginning of the Julian year. For the Itapiuru and Paraguaçu rivers basins, this fact affects the timming of the maximum flows.

The historical streamflow series available for the studied areas were limited in terms of extent and with certain inconsistencies in their values. So, even with the differences between the simulated data and the observed data, and knowing that there are modelling associated errors and uncertanties in the simulated series, it was assumed that the series of the synthetized data were valid for the studies, once the comparison with the observed data resulted in a same final classification and the availability and quality of the observed data did not allow the accomplishment of the studies here presented.

It is further stressed that the study here developed considered the impact of operation of dams individually on modeling the water system, being desirable to take into account the conditions of simultaneous operation of dams and their cumulative impact in future works.

\section{ACKNOWLEDGEMENTS}

To the Bahia Research Foundation (FAPESB) for granting the masters scholarship and for supporting the Granbar Networking Project in which this study was part of.

\section{REFERENCES}

AGOSTINHO, A. A.; GOMES, L. C.; PELICICE, F. M. Ecologia e manejo de recursos pesqueiros em reservatórios do Brasil. Maringa: Eduem, 2007. $501 \mathrm{p}$.

ANA - AGÊNCIA NACIONAL DE ÁGUAS. Bacia Hidrográfica do Rio Itapicuru - BA. Brasília, 2014.

BAHIA. SRHSH - Secretaria de Recursos Hídricos, Saneamento e Habitação. Plano de Bacia Hidrográfica do rio Paraguaçu. Salvador, 1993.

BAHIA. Superintêndencia de Recursos Hídricos. Monitoramento da qualidade das águas dos reservatórios de Apertado, Bandeira de Melo, França, Pedras Altas, Pindobaçu, Ponto Novo e São José do Jacuípe -PR. Salvador, 2008. 13 Relatório Final de Monitoramento da Qualidade da água, 6: Reservatório de Apertado.

BATALLA, R. J.; GÓMEZ, C. M.; KONDOLF, G. M. Reservoirinduced hydrological changes in the Ebro River basin (NE Spain). Journal of Hydrology (Amsterdam), v. 290, n. 1-2, p. 117-136, 2004. http://dx.doi.org/10.1016/j.jhydrol.2003.12.002.

BLACK, A. R.; ROWAN, J. S.; DUCK, R. W.; BRAGG, O. M.; CLELLAND, B. E. DHRAM: a method for classifying river flow regime alterations for the EC Water Framework Directive. Aquatic Conservation Marine and Freshwater Ecosystems., v. 17, n. 15, p. 427446, 2005. http://dx.doi.org/10.1002/aqc.707.

BUNN, S. E.; ARTHINGTON, A. H. Basic principles and ecological consequences of altered flow regimes for aquatic 
biodiversity. Environmental Management, v. 30, n. 4, p. 492-507, 2002. PMid:12481916. http://dx.doi.org/10.1007/s00267-002-2737-0.

CADE, B. S. National Hydrologic Assessment Tool: NATHAT. Virgínia: U.S. Geological Survey, 2006.

CBDB - COMITÊ BRASILEIRO DE BARRAGENS. Cadastro de barragens. Rio de Janeiro, 2004. Disponível em: <http://www. cbdb.org.br/barragem.htm>. Acesso em: 16 nov. 2015.

CERB - COMPANHIA DE ENGENHARIA E RECURSOS HÍDRICOS DA BAHIA. Fichas de operação das barragens. Salvador, 2004.

COLLISCHONN, W.; BUARQUE, D. C. PAIVA, R. C. D.; FAN, F. M.; KAYSER, R. Manual do Modelo de Grandes Bacias, MGB-IPH. Porto Alegre: UFRGS, 2010. Manual introdutório para aplicação do modelo MGB-IPH.

CRUZ, G. R. Simulação da Sað̧onalidade natural do rio Itapicuru. 2013. 84 f. Trabalho de Conclusão de Curso - Centro de Ciências Exatas e Tecnológicas, Universidade Federal do Recôncavo da Bahia, Cruz das Almas, 2013.

DITTMANN, R.; FROEHLICH, F.; POHL, R.; OSTROWSKI, M. Optimum multi-objective reservoir operation with emphasis on flood control and ecology. Natural Hazards and Earth System Sciences, v. 9, n. 6, p. 1973-1980, 2009. http://dx.doi.org/10.5194/ nhess-9-1973-2009.

FANTIN-CRUZ, I.; PEDROLLO, O.; GIRARD, P.; ZEILHOFER, P.; HAMILTON, S. K. Changes in river water quality caused by a diversion hydropower dam bordering the Pantanal floodplain. Hydrobiologia, v. 768, p. 223-238, 2015.

FIUZA, F.; OLIVEIRA, R. P.; FERREIRA, M. T. Seleção de parâmetros hidrológicos para avaliação da alteração do regime de escoamento em Portugal Continental. Recursos Hídricos, v. 35, n. 2 , p. $5-18,2014$.

FONTES, A. S.; GENZ, F.; ALMEIDA, R. A. S. SOUZA, N. C. R.; CRUZ, G. R. Avaliação do impacto bidrológico de grandes barragens do Estado da Babia - GRANBAR. Cruz das Almas: Universidade Federal do Recôncavo da Bahia, 2014.

FONTES, A. S.; OLIVEIRA, J. I. R.; MEDEIROS, Y. D. P. A evaporação em açudes no semiárido nordestino do Brasil e a Gestão das Águas. In: SIMPÓSIO BRASILEIRO DE RECURSOS HÍDRICOS, 15., 2005, João Pessoa. Anais... Porto Alegre: ABRH, 2005.

GENZ, F. Avaliação dos efeitos da barragem de Pedra do Cavalo sobre a circulação estuarina do rio Paraguaçu e Baía de Iguape. 2006. 266 f. Tese (Doutorado) - Instituto de Geociências, Universidade Federal da Bahia, Salvador, 2006.

GENZ, F.; LESSA, G. C. Twenty-six years of uneven changes in low flows due to different uses and operation of a large dam in a semiarid river. RBRH: Revista Brasileira de Recursos Hídricos, v. 20, n. 2, p. 523-532, 2015.

GENZ, F.; LUZ, L. D. Distinguishing the effects of climate on discharge in a tropical river highly impacted by large dams. Hydrological Sciences Journal, v. 57, n. 5, p. 1020-1034, 2012. http:// dx.doi.org/10.1080/02626667.2012.690880.

GENZ, F; SILVA, S. F; TANAJURA, C. A. S. Impacto das mudanças climáticas nas vazões do rio Paraguaçu - Cenário A1B de 2011 a 2040. In: SIMPÓSIO DE RECURSOS HÍDRICOS DO NORDESTE, 11., 2012, João Pessoa. Anais... Porto Alegre: ABRH, 2012.

INEMA - INSTITUTO DE MEIO AMBIENTE E RECURSOS HÍDRICOS. Barragens/ reservatórios: inventário das Barragens do estado da Bahia. Salvador, 2014a. Disponível em < http://www. inema.ba.gov.br/gestao-2/barragensreservatorios $>$ Acesso em 15 abr. 2014a.

INEMA - INSTITUTO DE MEIO AMBIENTE E RECURSOS HÍDRICOS. Comitê de Bacia Hidrográfica Itapicuru. Salvador, 2014b. Disponível em: <http://www.inema.ba.gov.br/gestao-2/comitesde-bacias/comites/cbh-itapicuru/>. Acesso em: 20 mai. 2014.

JUNK, W. J.; BAYLEEY, P. B.; SPARKS, R. E. The flood pulse concept in River-Floodplain systems. Canadian Special Publication of Fisheries and Aquatic Sciences, v. 106, p. 110-127, 1989.

LIMA, C. H. P. Avaliação das alterações hidrológicas a jusante de barragens por meio de análise de sensibilidade à variação de variáveis de projeto. 2014. 231 f. Dissertação (Mestrado) - Escola Politécnica, Universidade Federal da Bahia, Salvador, 2014.

MARTÍNEZ, C. S.; YUSTE, J. A. F. LAHRIS 2.2: índices de alteración hidrológica en ríos: manual de referencia metodológica. Madrid: Universidade Politécnica de Madrid, 2010.

MEDEIROS, Y. D. P. (Coord.) Subprojeto Sistema de Apoio a Decisão para o Gerenciamento dos Recursos Hídricos da Bacia do rio Paraguaçu. In: Relatório do Projeto Gerenciamento de Recursos Hídricos do Semi-árido do Estado da Babia. Salvador: Universidade Fderal da Bahia, 2004. v. 3, cap. 7.

OLDEN, J. D.; POFF, N. L. Redundancy and the choice of hydrologic indices for characterizing streamflow regimes. River Research and Applications, v. 19, n. Jan, p. 101-121, 2003. http:// dx.doi.org/10.1002/rra.700.

POFF, N. L.; ALLAN, J. D.; BAIN, M. B.; KARR, J. R.; PRESTEGAARD, K. L.; RICHTER, B. D.; SPARKS, R. E.; STROMBERG, J. C. The natural flow regime: a paradigm for river conservation and restoration. Bioscience, v. 47, n. 11, p. 769-784, 1997. http://dx.doi.org/10.2307/1313099.

RICHTER, B. D.; BAUMGARTER, J. V.; POWELL, J.; BRAUN, D. P. A method for assessing hydrologic alteration within ecosystems. 
Conservation Biology, v. 10, n. 4, p. 1163-1174, 1996. http://dx.doi. org/10.1046/j.1523-1739.1996.10041163.x.

RICHTER, B. D.; BAUMGARTNER, J. V.; WIGINGTON, R.; BRAUN, D. P. How much water does a river need? Freshwater Biology, v. 37, n. 1, p. 231-249, 1997. http://dx.doi.org/10.1046/j.13652427.1997.00153.x.

SANTOS, C. P.; SOUZA, C. F. Efeitos da cascata de reservatórios sobre a variabilidade natural de vazões: o caso do rio Paraná em Porto Primavera. RBRH: Revista Brasileira de Recursos Hídricos, v. 20, n. 3, p. 698-707, 2015.

SANTOS, V. C.; CONCEIÇÃO, M. P. S.; FONTES, A. S. Comparação das alterações hidrológicas ocorridas nos rios Paraguaçu e Itapicuru decorrentes das barragens de Bandeira de Melo e Pedras Altas. In: SIMPÓSIO BRASILEIRO DE RECURSOS HÍDRICOS 21., 2015, Brasília. Anais... Porto Alegre: ABRH, 2015.

SEI - STOCKHOLM ENVIRONMENT INSTITUTE. Water Evaluation and Planning - WEAP: user guide for WEAP21. Boston, 2011.

SILVA, S. F. Análise da disponibilidade e demanda para o sistema de abastecimento de água em Salvador frente ao cenário de mudanças climáticas. 2012. 150 f. Dissertação (Mestrado) - Escola Politécnica, Universidade Federal da Bahia, Salvador, 2012.

SOARES, L.; SANTOS, H.; MARTINEZ-CAPEL, F.; CALLISTO, M.; TUPINAMBÁS, T.; CASTRO, D.; FRANÇA, J.; POMPEU, P.; SAMPAIO, F.; GANDINI, C. L. J. V.; ALVEZ, C. Metodología para la propuesta de cudales ecológicos em función de restricciones ambientales y de gestión. Aqua-L AC., v. 7, n. 2, p. 17-28, 2015.

SOKOLONSKI, H. H.; COSTA, N. L. Zoneamento Geoambiental da Bacia do Alto Paraguaçu: diretrizes gerais para a ordenação territorial. Rio de Janeiro: IBGE, 1996. 17 p.

SOUZA, C. F. Vazões ambientais em hidrelétricas: Belo Monte e Manso. 2009. 163 f. Tese (Doutorado) - Instituto de Pesquisas Hidráulicas, Universidade Federal do Rio Grande do Sul, Porto Alegre, 2009.

STANFORD, J. A.; WARD, J. V.; LISS, W. J.; FRISSELL, C. A.; WILLIAMS, R. N.; LICHATOWICH, J. A.; COUTANT, C. C. A general protocol for restoration of regulated rivers. Regulated Rivers: Research and Management, v. 12, n. 4-5, p. 391-413, 1996. http:/ / dx.doi.org/10.1002/(SICI)1099-1646(199607)12:4/5<391::AIDRRR436>3.0.CO;2-4.

STEVAUX, J. C.; CORRADINI, F. A.; AQUINO, S. Connectivity process and riparian vegetation of the upper Paraná River, Brazil. Journal of South American Earth Sciences, 2012.

TNC - THE NATURE CONSERVANCY. Indicators of bydrologic alteration: version 7.1: user's manual. Arlington, 2009.

VAZ SAMPAIO, C. B. Estudo e Diagnóstico da Agricultura Irrigada na Região do Alto da Bacia Hidrográfica do Rio Itapicuru - Babia. 2006. 191 p. Dissertação (Mestrado) - Faculdade de Engenharia Agrícola, Universidade Estadual de Campinas, Campinas, 2006.

ZHANG, Q.; GU, X.; SINGH, V. P.; CHEN, X. Evaluation of ecological instream flow using multiple ecological indicators with consideration of hydrological alterations. Journal of Hydrology (Amsterdam), v. 529, n. 3, p. 711-722, 2015. http://dx.doi. org/10.1016/j.jhydrol.2015.08.066.

\section{Authors contributions}

Naiah Caroline Rodrigues de Souza: Bibliographic research, data collection and treatment, hydrological simulation, statistical tool application, analysis and discussion of the results and elaboration of the text.

Andrea Sousa Fontes: Guidance of the study, contribution in the definition and execution of the methodology, discussion of the results and revision of the text.

Lafayette Dantas da Luz: Guidance of the study, contribution in the definition and execution of the methodology, discussion of the results and revision of the text.

Sandra Maria Conceição Pinheiro: Contribution in the definition and execution of the methodology, statistical analysis of data. 